\title{
Corporate Social Responsibility Effect on Information Asymmetry
}

\author{
Rizky Eriandani \\ Universitas Surabaya \\ Universitas Airlangga \\ rizky.eriandani@staff.ubaya.ac.id
}

\begin{abstract}
This study was aimed to answer the question of whether Corporate Social Responsibility (CSR) disclosure as one form of voluntary disclosure can reduce the asymmetric information in Indonesian capital market, as a developing country. In other words, whether information about the performance of CSR provides benefits to investors by reducing uncertainty. The 267 samples used were all companies listed on the Indonesia Stock Exchange from 2014 to 2015, except for the financial and banking industries. Asymmetry information would be measured with bid-ask spreads, the larger the spread, the higher the asymmetry information. CSR disclosure would be measured by content analysis, using the index of previous research that has been adjusted to the conditions in Indonesia, then the sample will be separated based on the mining industry, manufacturing, and services. The results of this study showed that the disclosure of corporate social responsibility could reduce information asymmetry. Companies in the manufacturing industry were more sensitive to social and environmental issues (covered by CSR activities) so that CSR information on this industry was more relevant to investors than to the service industry.
\end{abstract}

Keywords-social responsibility; information asymmetry; industry effect.

\section{INTRODUCTION}

Information asymmetry occurs when there are parties who have more knowledge or information (Informed) about the actual company condition than the other (Uninformed). The topic of information asymmetry can be said to be quite important, because every company usually encounters the problem. Healy and Palepu [1] said that the company will disclose all information regarding private information in order to reduce the problem of information asymmetry. Reporting and retrieving financial statements are an important tool for management to communicate firm performance and corporate governance to investors.

The previous studies used cost of capital variable as a proxy for measuring information asymmetry. The negative relationship between corporate disclosure and cost of capital is explained by two perspectives. First -Liquidity perspective, where disclosure reduces the cost of equity financing of a company by improving liquidity in the future [2]. Second -Risk perspective, defines cost of capital as the minimum rate of return requested by investors, including risk free rate and premium rate from non-diversified risk [3]. Thus, reducing the information gap, at least reduce the component of estimate of the risk. In conclusion, both perspectives stated that corporate disclosure affects cost of capital by reducing information asymmetry.

One of voluntary disclosure study was conducted by Diamond and Verrecchia [2]. The study described that earnings announcements can reduce the cost of information processing individually or institutionally because information received by market participants is relatively similar. The aggregate processing costs of these market participants will affect market liquidity. If processing costs are high (as the asymmetry information increases), the market becomes less liquid. Declining liquidity and increasing asymmetric information will lead to high security prices, so cost of capital also increases. Amihud and Mandelson [4] stated that companies that provide much information to the public can reduce the adverse selection component of bid-ask spreads, potentially reducing the company's cost of equity capital. From the description above, it can be concluded that there are several ways that can be used to reduce the problem of information asymmetry, and this study focuses on voluntary disclosure area.

Today, the Company can not only seek profit for shareholders, but must also pay attention to the welfare of other stakeholders so that the company can avoid external pressure [5]. Corporate Social Responsility (CSR) has become a very important world issue. As evidenced by the emergence of Global Compact, Global Reporting Initiatives (GRI), and ISO 26000. Responsibility for environmental, social and community development issues is no longer just a matter of government, but also the responsibility of the private sector. This is in line with the argument of freeman [6] which stated that social activity initiatives are not only due to the moral obligation to benefit society, but also to ensure the sustainability of the company.

In the preceding paragraph, has explained the importance of social activities for the company. Further, the activities the company has undertaken should be disclosed in the annual report to be made known to all stakeholders. The financial statements are a signal to communicate an important information that corporate management has, for example, projections of management and profitability. Some investors view financial statements that do not provide adequate levels of 
disclosure, as risky financial statements. If investors value high-risk firms based on the resulting financial statements, then the expected return value by investors is also high, which in turn will cause the high cost of equity to be incurred by the company [7].

The previous studies found similar results, i.e. disclosure of CSR negatively associated with information asymmetry, although using different proxies. Cui, Jo, and $\mathrm{Na}$ [8] found that CSR had a negative effect on information asymmetry. In addition, CSR activities at high risk firms, leading to a greater decline in information asymmetry. In other words, corporate risk plays a negative mediation role between CSR and information asymmetry. Therefore, the study suggests that high-risk firms tend to make more efforts to disseminate information (in this case, CSR activity) that can be trusted to outside investors and to reduce information asymmetry between insider and outsider. Lu and Chueh [9] showed the results of test that there is a significant negative relationship between CSR and information asymmetry, which means the market responds to CSR by minimizing the gap between bidask spreads. Cho, Lee, and Pfeiffer [10] also found the same thing, positive and negative CSR information can decrease the asymmetry of information in the capital market. It also found no relationship between CSR performance and information asymmetry, in companies with higher institutional ownership (as informed shareholders),

Although the previous study has shown similar results, the numbers are still very limited. In Indonesia, CSR topics that are associated with asymmetric information are very few, and have not been properly published. Diebecker and Sommer's [11] research developed CSR topics and asymmetric information that have been made in the United States, looking at differences in country characteristics in Europe (e.g. governance structure in Europe is different from that in the United States). Based on these facts, the authors are interested in researching voluntary disclosure, in this case is CSR, and its relation to information asymmetry on the business entity listed on the BEI. The main hypothesis will be developed with additional analysis, where the sample will be separated by industry. Separation of this industry is considered important, because it has different characteristics. Firm performance in the same industry tends to have similarities because they face similar drivers, including CSR performance. The industry plays a role in the intensity of social responsibility because of the pressure of industryspecific stakeholder pressures to improve social responsiveness [12]. So, it can be said that CSR information for a particular industry has a specific role.

This study aims to answer the question whether the disclosure of CSR as one form of voluntary disclosure can reduce information asymmetry in Indonesia capital market, as one of the developing countries. In other words, does information on CSR performance give a benefit for investors by reducing uncertainty. Furthermore, the sample used is all companies listed on the Indonesia Stock Exchange from 2014 to 2015, except for the financial and banking industries. Asymmetry information will be proxyed with bid-ask spreads, the larger the spread, the higher the asymmetry information. CSR disclosure will be procured with dummy and index sembiring, because it has been adjusted to the conditions in
Indonesia, then the sample will be separated based on manufacturing, and services industry.

This study is expected to contribute to the development of literature. First, the results of the study will show whether CSR disclosure also negatively impacts the asymmetry information in the Indonesian capital market. Second, provide potentially useful insights into policy implications for regulators. In the next section, the second section will explain the theory and development of the hypothesis. The third section deals with research methods. Furthermore, the discussion of research results, and the last conclusions and limitations of research.

\section{THEORY AND HYPOTHESES}

The previous research has examined the benefits of CSR implementation using the company's financial performance measures (CFPs) and has found that CSR benefits firms in the following ways: firms get greater attention from analysts [13] and receive good recommendations From analysts [14]; CSR improves communication to shareholders related to financial issues [15]; CSR encourages more effective corporate governance and higher corporate values[16] ; CSR reduces the cost of equity [17]; CSR improves credit rating [18] and results in higher accuracy analyst estimates [19].

Disclosure can help reduce undiversified risk, so it will affect the cost of capital through several mechanisms. First, transparency of disclosure reduces information asymmetries between investors, and between managers and investors, so investors have greater willingness to transact, thus encouraging liquidity [4]. Larger disclosure may lead to reduced information asymmetry between investors or between managers and investors. When disclosure levels are inadequate, and there is a perception that some investors are considered better informed, informationally disadvantaged investors will tend to price-protect to protect themselves from being less willing to transact. As a result, illiquid increases bid-ask spreads and transaction costs [20], and encourages higher required return or cost of equity capital [4]. Second, disclosure reduces risk and uncertainty estimates in asset pricing models used by investors [7]. Third, high levels of transparency reduce monitoring costs for investors, so they ask for a lower rate of return than holding stock.

From the description above, it can be said to provide relevant information about the company's business practices will be able to reduce asymmetry information, and also reduce the uncertainty faced by investors.

$\mathrm{H}_{1}$ : The more Disclosure of CSR will reduce the level of information asymmetry

\section{METHOD}

\section{A. Sample}

This study used a secondary data, namely financial statements and annual reports downloaded from the Indonesia Stock Exchange website (www.idx.co.id). The sampling 
technique used was non probability sampling - purposive judgment sampling. This was because not all companies listed on the BEI between January 1, 2014 - December 31, 2015, could be selected as a sample. Table 1 showed the sample of the study. The selected sample was a member of the population that has met the criteria to which the criteria restrictions were based on the author's judgment. These criteria include:

a) Companies listed on the Stock Exchange between 1 January 2014 to 31 December 2015, excluding banking and finance sectors.

b) Has issued its annual financial statements for the periods ended December 31, 2014 to December 31, 2015, denominated in Indonesian Rupiah.

c) The company publishes the annual report of each company for the period 2014. 2015 .

d) The bid ask price data for the issuer is available in

TABLE I. SAMPLE

\begin{tabular}{|l|l|c|}
\hline \multirow{2}{*}{ No. } & \multicolumn{2}{|c|}{ Sample Criteria } \\
\cline { 2 - 3 } & \multicolumn{1}{|c|}{ Description } & Subtotal \\
\hline 1 & Total issuer 2014 & 518 \\
\hline 2 & Annual report data is not available & 28 \\
\hline 3 & IPO 2014-2015 & 22 \\
\hline 4 & Issuers that are not listing in 2015 & 86 \\
\hline 6 & Incomplete stock price data & 35 \\
\hline 7 & $\begin{array}{l}\text { Incomplete performance profile data / not } \\
\text { available }\end{array}$ & 12 \\
\hline 8 & Not disclosing CSR activity & 46 \\
\hline & Total sample & $\mathbf{2 6 7}$ \\
\hline
\end{tabular}

\section{B. Definition and measuremet of variables}

The dependent variable in this study was the asymmetry information proxyed by bid-ask spread. The definition of a bidask spread is the difference between the highest demand value the investor wants to sell and the lowest bid the investor wants to buy. The reason for using the proxy was because bid ask spread is intended to see the adverse selection problem arising from stock transactions where the information obtained by investors is not the same [21]. The smaller the information asymmetry indicates lower adverse selection, and can be seen from lower bid ask spreads. Measurement of spread variables was done by calculating the average daily Bid-ask spread rate, for one year (annually), from April to the issuance of the financial statements until March of the following year.

Independent variable in this study was Corporate Social Responsibility. The study used a disclosure proxy to measure CSR, with content analysis. The measurement instruments of CSDI used in this study was adopted from the previous study. The instrument was derived from Hackston and Milne's [22] study, which has been adjusted to the Bapepam Regulations, and eliminates 12 items (out of a total of 90 items) because they are less suitable for application in Indonesia. So, a total of 78 items, where each industry had the maximum number of different disclosures. The calculation of CSRDI was obtained by comparing the number of social items disclosed with what should be disclosed.

\section{Equations}

This study use multiple linear regression model to answer the hypothesis - to know the influence between dependent variable and independent variable. The test of each hypothesis was done by testing each regression coefficient with t test. Multiple linear regression model is shown by the following equation.

$$
\begin{aligned}
& \operatorname{ASYM}_{\mathrm{i}, \mathrm{t}+1}=\alpha+\beta_{1} \mathrm{CSRDI}_{\mathrm{i}, \mathrm{t}}+\beta_{2} \mathrm{ROA}_{\mathrm{i}, \mathrm{t}+1}+\beta_{3} \mathrm{DER}_{\mathrm{i}, \mathrm{t}+1}+
\end{aligned}
$$

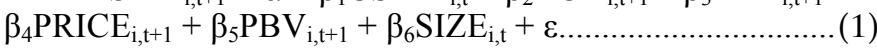

Keterangan:

$\begin{array}{ll}\text { ASYM } & =\text { Information asymmetry } \\ \alpha & =\text { Constanta } \\ \text { CSRDI } & =\text { CSR Disclosure } \\ \text { ROA } & =\text { Return on Assets } \\ \text { DER } & =\text { Debt to Equity ratio } \\ \text { SIZE } & =\text { Company size (Log Assets) } \\ \text { PRICE } & =\text { Closing Price (daily) } \\ \text { PBV } & =\text { Price to book value }\end{array}$

\section{RESULTS AND DISCUSSION}

Table 2 showed Pearson correlation between research variables. Bid-ask spread (ASYM) was negatively correlated with CSR disclosure. Other variables, also proved consistent with previous research, such as the negative correlation between bid-ask spread and firm performance (ROA), PRICE, and firm size (SIZE). These results provided initial support for hypothesis testing. Furthermore, the classical assumption tested on the data of the study. Normality test at full sample, from total sample 267, got 26 outlier, so the test sample become 241 . With 241 sample amounts, got Asymp value. Sig. (2-tailed) of 0.016 , so it was concluded that the data distribution was not normal, although all outlier data has been removed. This was a limitation of the study. But when the study sample was separated, the data became normal. Testing of data normality in manufacture industry, got total sample 106, without outlier, with value of Asymp. Sig. (2-tailed) of 0.257 (normal data). Normality testing of the service industry, out of a total of 161 samples, obtained outlier 15 , so the test sample became 146 , indicating the value of Asymp. Sig. (2-tailed) of 0.229 (normal data). Other classical assumption tests (multicollinearity, heteroscedasticity, and autocorrelation) have been performed, and showed good results. 
Table 3 column 2 showed the estimation results of the regression model mentioned in equation (1). Focus on CSRI coefficients, proving the effect of CSR performance, as measured by the level of disclosures, on information asymmetry. The coefficient of CSRI was negative and statistically significant (-, 118 and significant at $10 \%$ level). These results suggested that CSR performance, could reduce information asymmetry. In Table 3 , columns 3 and 4 showed in the mining \& manufacturing industries, and services industried, CSR disclosure negatively impacted the asymmetric information.

TABLE II. CORRELATION

\begin{tabular}{|c|c|c|c|c|c|c|c|}
\hline \multirow{2}{*}{$\begin{array}{c}\text { Variab } \\
\text { le }\end{array}$} & \multicolumn{7}{|c|}{ Variable } \\
\hline & (1) & (2) & (3) & (4) & (5) & (6) & (7) \\
\hline ASYM & 1 &,- 083 &,- 024 &,- 070 &,- 006 & ,029 &,- 070 \\
\hline CSRI &,- 083 & 1 & ,097, & ,011 &,- 034 &,- 032 &, $384^{*}$ \\
\hline ROA &,- 024 & ,097 & 1 &,- 001 &, $298^{* *}$ &,$- 137^{*}$ &,- 040 \\
\hline DER &,- 070 &, 011 &,- 001 & 1 & ,017 & $\overline{-}, 312^{* * *}$ &, $3211^{*}$ \\
\hline PRICE &,- 006 &,- 034 & ,298 & ,017 & 1 &, $179^{* *}$ &,- 011 \\
\hline PBV & 029 &,- 032 &,$- 137^{*}$ &,$- 312^{* *}$ & , $179^{* *}$ & 1 &, 004 \\
\hline SIZE &,- 070 &, $384^{* *}$ &,- 040 &, $321^{* *}$ &,- 011 & 004 & 1 \\
\hline
\end{tabular}

This means that CSR disclosure could reduce the information gap and uncertainty faced by investors. While in service industry, the negative effect of CSRI on asymmetric information was not significant. The control variables showed varying results, some significant variables, but all had directions corresponding to predictions.

TABLE III. CSR AND ASYMMETRY INFORMATION

\begin{tabular}{|c|c|c|c|}
\hline \multirow{2}{*}{ Variable } & \multicolumn{3}{|c|}{ Industry } \\
\cline { 2 - 4 } & $\boldsymbol{A l l}$ & $\begin{array}{c}\text { Manufactur } \\
\boldsymbol{e}\end{array}$ & Services \\
\hline intercept & $-2,548$ & $-1,745$ & $-1,143$ \\
\hline CSRI & $\mathbf{- , 1 1 8 *}$ & $\mathbf{- 1 , 6 6 4 *}$ &,- 127 \\
\hline ROA & $\mathbf{- , 1 2 5 *}$ & $\mathbf{- 2 , 0 1 5 * *}$ &,- 107 \\
\hline DER &,- 099 & $-1,495$ &,- 132 \\
\hline PRICE &, 106 &,- 704 &, $232^{* *}$ \\
\hline PBV &,$- 126^{*}$ & $2,449 * *$ &,- 075 \\
\hline SIZE &,- 064 &,- 344 &,- 140 \\
\hline
\end{tabular}

The results of this study in accordance with the proposed hypothesis, proving that corporate social disclosure responsiblity as one of the voluntary disclosures made by the company, could reduce information asymmetry. This supports the theory of signaling, indicating that CSR disclosure is relevant information for investors to assess company performance or reduce cost of capital. When CSR information was considered relevant, the level of disclosure was considered adequate, and made the information gap between investor and management (or between block holder and minority) reduced. When information was judged to be lacking, investors would tend to price-protect to protect themselves and became less willing to transact. This proved a significant negative relationship between CSR and asymmetric information, which means the market responds with a smaller bid-ask spreads gap.

The results of this study were in line with previous study, Cui, Jo, Na [8] which proved an inverse relationship between CSR and the level of information asymmetry, with control variables of various firm characteristics. The $\mathrm{Lu}, \mathrm{Chia}-\mathrm{Wu}$ and Chueh's [9] study showed a significant negative relationship between CSR and information asymmetry, which means the market responds to CSR by minimizing the gap between bidask spreads. The study used Bid-Ask Spread and Amihud illiquidity proxies to measure information asymmetry.

Given that asymmetric information could cause investors to lose, the regulator always asks the listed company to disclose all information in a transparent manner. Given the information asymmetry and its impact on the stock market, solutions must be found to improve reporting quality so as to get back investor confidence. One solution to the problem of information asymmetry was the existence of the principle of full disclosure to increase the likelihood that all information can be known by the public. It was hoped that regulations on CSR disclosure could minimize the information gap between informed and uninformed bodies.

Furthermore, this study separated the sample by industry. Industrial effects were an important factor to consider in CSR intensity [23]. When the research sample was separated into two groups, manufacturing and services, the results showed that in the manufacturing industry CSR disclosure was able to reduce asymmetric information, while in the service industry, no significant effect. Companies in the manufacturing industry were more sensitive to social and environmental issues (covered by CSR activities) so that CSR information on this industry was more relevant to investors than to the service industry. The results of the study provided implications for policy makers in Indonesia. CSR disclosure was able to reduce the information gap between investors and management, particularly in manufacturing and mining industries.

\section{CONCLUSION}

The results support the proposed hypothesis, the disclosure of CSR can reduce the level of information asymmetry. However, there are some limitations in this study, firstly, the data used in full sample testing has an abnormal distribution even though all outliers have been excluded, but in a separate sample, the data is normally distributed. The author had also tried to process data using smartpls, and found the results were not much different. Second, CSR disclosure still has not been grouped by CSR activity category, economic, environmental, social. Third, industry groupings are only based on manufacturing and services, not grouped by sub-industry yet. 


\section{REFERENCES}

[1] P. M. Healy and K. G. Palepu, "Information asymmetry, corporate disclosure, and the capital market: A review of the empirical disclosure literature,” J. Account. Econ., vol. 31, pp. 304-440, 2001.

[2] D. W. Diamond and R. . Verrecchia, "Disclosure, Liquidity, and the cost of capital," J. Finance, vol. 46, no. 4, pp. 1325-1359, 1991.

[3] C. A. Botosan, "Disclosure level and the cost of equity capital," Account. Rev., vol. 72, pp. 323-349, 1997.

[4] Y. Amihud and M. H, "Asset pricing and the bid-ask spread," J. financ. econ., vol. 17, pp. 223-249, 1986.

[5] M. Orlitzky, F. L. Schmidt, and S. L. Rynes, "Corporate Social and Financial Performance: A Meta Analysis.," Organ. Stud., vol. 24, no. 3, pp. 403-441, 2003.

[6] R. Freeman, Strategic management: A stakeholder approach Marshfield: Pitman Publishing Inc, 1984.

[7] J. Coles, N. Daniel, and L. Naveen, "Managerial incentives and risktaking," J. Financ. Econ, vol. 79, pp. 431-468, 2006.

[8] J. Cui, H. Jo, and H. Na, "Does Corporate Social Responsibility Affect Information Asymmetry?,” J. Bus. Ethics, 2016.

[9] C.-W. $\mathrm{Lu}$ and T. Chueh, "Corporate Social Responsibility and Information Asymmetry,” J. Appl. Financ. Bank., vol. 5, no. 3, pp. 105 122, 2015.

[10] S. Cho, C. Lee, and R. Pfeiffer, "Corporate social responsibility performance and information asymmetry," J. Account. Public Policy, vol. 32, no. 1, pp. 71-83, 2013.

[11] J. Diebecker and F. Sommer, "The impact of corporate sustainability performance on information asymmetry: the role of institutional differences.," Rev Manag Sci., 2016.

[12] R. C. Moura-Leite, R. C. Padgett, and J. I. Galan, "Is social responsibility driven by industry or firm-specific factors?," Manag. Decis., vol. 50, no. 7, pp. 1200-1221, 2012.

[13] H. Hong and M. Kacperczyk, "The price of sin: The effects of social norms on markets," J. financ. econ., vol. 93, pp. 15-36, 2009.

[14] I. Ioannou and G. Serafeim, "The Consequences of Mandatory Corporate Sustainability Reporting: Evidence from Four Countries," 2014.

[15] C. Fieseler, "On the CSR perceptions of financial analysts.," Bus. Ethics A Eur. Rev., vol. 20, no. 2, pp. 131-147, 2011.

[16] H. Jo and M. Harjoto, "Corporate governance and firm value: The impact of corporate social responsibility," J. Bus. Ethics, vol. 103, no. 3, pp. 351-383, 2011.

[17] D. Dhaliwal, A. T. O. Li, and Y. Yang, "Voluntary Nonfinancial Disclosure and the Cost of Equity Capital: The Initiation of Corporate Social Responsibility Reporting," Account. Rev., vol. 86, no. 1, pp. 59100, 2011.

[18] N. Attig, S. Cleary, S. Ghoul, and O. Guedhami, "Institutional investment horizons and the cost of equity capital," Financ. Manag., vol. 42, no. 2, pp. 441-477, 2013.

[19] D. Dhaliwal, S. Radhakrishnan, A. Tsang, and Y. Yang, "Nonfinancial Disclosure and Analyst Forecast Accuracy: International Evidence on Corporate Social Responsibility Disclosure," Account. Rev., vol. 87, no. 3, pp. 723-759, 2012.

[20] Verrechia and Robert.E., "Essay on disclosure," J. Account. Econ., vol. 32, pp. 97-108, 2001.

[21] C. Leuz and R. E. Verrecchia, "The economic consequences of increased disclosure," J. Account. Res., vol. 38, 2000.

[22] D. Hackston and M. J. Milne, "Some determinants of social and environmental disclosures in New Zealand companies," Accounting, Audit. Account. J., vol. 9, no. 1, pp. 77-108, 1996.

[23] Moura-Leite, R. C., R. C. Padgett, and J. I. Galan., "Is social responsibility driven by industry or firm-specific factors?," Manag. Decis., vol. 50, no. 7, pp. 1200-1221, 2012. 